\title{
3D SURVEYING AND GEOMETRIC ASSESSMENT OF A GOTHIC NAVE VAULTING FROM POINT CLOUDS.
}

\author{
A. Costa-Jover ${ }^{\mathrm{a}^{*}}$, J. Lluis i Ginovart ${ }^{\mathrm{b}}$, S. Coll-Pla ${ }^{\mathrm{a}}$, M. López Piquer ${ }^{\mathrm{b}}$, A. Samper-Sosa ${ }^{\mathrm{a}}$, D. Moreno García ${ }^{\mathrm{a}}$, A.M. Solís \\ Lorenzo $^{\mathrm{a}}$ \\ ${ }^{a}$ Department of Architecture, Universitat Rovira i Virgili, Av. Universitat 1, Campus Bellissens, 43204 Reus, Spain - \\ *agusti.costa@urv.cat \\ ${ }^{\mathrm{b}}$ School of Architecture of Barcelona, Universitat Internacional de Catalunya, C/ Immaculada 22, Edifici Alfa, 08017 Barcelona, \\ Spain-jlluis@uic.es
}

Commission II

KEY WORDS: terrestrial laser scanner, geometrical assessment, gothic, vaults, Cathedral of Tortosa.

\begin{abstract}
:
The development of massive data captures techniques (MDC) in recent years, such as the Terrestrial laser Scanner (TLS), raises the possibility of developing new assessment procedures for architectural heritage. The 3D models that it is able to obtain is a great potential tool, both for conservation purposes and for historical and architectural studies. The paper proposes a simple, non-invasive methodology for the assessment of masonry vaults from point clouds which makes it possible to obtain relevant data about the formal anomalies. The methodology is tested in Tortosa's Gothic Cathedral's vaults, where the geometrical differences between vaults, a priori equal, are identified and related with the partially known construction phases. The procedure can be easily used on any other vaulted construction of any kind, but is especially useful to deal with the complex geometry of Gothic masonry vaults.
\end{abstract}

\section{INTRODUCTION}

The architectural heritage topographic documentation is a key tool for its preservation. Current techniques of Massive Data Capture (MDC), such as digital photogrammetry and terrestrial laser scanner, have become widespread in the assessment of built heritage (Pavlidis et al. 2007). They are especially useful for historical constructions, since the architecture is complex and irregular. In addition, many elements such as, vaults and domes, are not accessible (Yilmaz et al. 2007), (Fassi et al 2011), (Martínez et al. 2013).

Terrestrial Laser Scanner is a contactless, non-invasive technique that has recently become prominent because of its speed and simplicity. In addition, the recent years' technical development has allowed cost reduction (Lerones, Fernández, Gil, Gómez-García-Bermejo, \& Casanova, 2010). It is possible to survey complex spaces, such as architectural and archaeological heritage, in a short time and with great precision (Lerma García \& Biosca Tarongers 2008). Numerous investigations have tested the technique's reliability (Kadobayashi et al. 2004), (Grussenmeyer et al. 2008), and has proven their effectiveness to survey the building's geometry with high precision. The point clouds make possible to detect and monitor degradation processes and formal anomalies, but also to enhance the historical knowledge about the analysed element. This paper focuses on this aim, specifically the case of the Tortosa's Gothic Cathedral (1345-1757), where the use of a Terrestrial Laser Scanner allowed to survey the vaulting with an unprecedented accuracy. The investigation proposes a simple methodology to analyse the Gothic vaults, and put special emphasis on the results' interpretation.

The Gothic Cathedral's survey has to deal with the architectural forms complexity and the huge building scale. Some works have approached these structures survey, being the case of Santiago de Compostela's Cathedral (Martínez et al. 2013), Milan's Cathedral (Fassi et al. 2011) or the Cathedral of St. Johannis in Meldorf (Sternberg 2006). Many works have used these data to deepen in the history and buildings constructions, such as the cases of of Santa María del Mar church (Vendrell et al. 2008) or Avila Cathedral (Benito 2011). The deformation assessments are essential for architectural heritage conservation, and many studies have developed simple procedures to address that issue from the 3D topographical information of the point clouds, i.e. the churches of Santa Maria in Portonovo (Quagliarini et al. 2016) and Cantalovo (Bonali et al. 2014) or the Palazzo d'Accursio (Pesci et al. 2012), all in Italy. Those investigation focuses on the assessment of vertical elements deformations, except the Portonovo's case, where a simple assessment of the cylindrical barrel vaults is performed from standard primitives.

\subsection{Tortosa's Cathedral}

Tortosa's Cathedral (1345-1757) is one of the most important buildings of Southern Gothic. It is a basilica floor plan building with a heptagonal apse (1345-1757), a double ambulatory, and a central body (1441-1757) with three naves and lateral chapels, that is divided into five structural sections and a Baroque facade. The space is covered by quadripartite ribbed vaults, built on a cross section with three levels in height. The basic unit of measure identified in the apse is Tortosa palm, with an equivalence of $(1 \mathrm{palm}=23.23 \mathrm{~cm})$ (Lluis i Ginovart et al. 2013).

The first Tortosa Cathedral computerized topography was performed between 1995 and 2000 for the Master Plan Sancta Maria Dertosae (Lluis i Ginovart \& Llorca 2000). The data captured for the survey was conducted using direct measurements that were referenced to polygonal points fixed by a total station. The numerical data were processed using CAD applications, which enabled a survey with an error of approximately $3 \mathrm{~cm}$. The representation of the floor plan has a precision that could hardly be improved with available techniques, but in the case of the vaulted ceiling a detailed 
survey was impossible owing to technical and resource limitations. The MDC techniques' development has allowed to perform a new complete survey of Tortosa's Cathedral with unprecedented precision.

Several investigations have been developed in recent years about Tortosa's Cathedral. Those have addressed questions such as the geometrical layout of the apse (Lluis i Ginovart et al. 2013), (Lluis i Ginovart \& Costa Jover 2014), the construction history (Lluis i Ginovart, Costa-Jover, et al. 2014) and construction process (Lluis i Ginovart, Costa Jover, et al. 2015), (Lluis i Ginovart, Costa-Jover, et al. 2015) or also questions about the stone-cutting (Lluis i Ginovart, Agustí Costa-Jover, et al. 2016).

Moreover, the recent development of survey techniques motivated the study of geometrical assessment of masonry vaults by means of MDC techniques, which were used in Tortosa's Gothic apse (1345-1441) (Lluis i Ginovart, Toldrà, et al. 2014), (Lluis i Ginovart, Costa, et al. 2014), (Lluis i Ginovart, Agusti Costa-Jover, et al. 2016). These studies revealed meaningful formal differences between vaults that were related to the apse's construction process. Thus, the methodology provided new data that goes beyond the available primary sources. These investigations are a direct forerunner of the research presented at this paper, where the work of the apse are completed with the Cathedral central body assessment. The study systematize the same methodology previously used, and incorporates new processes which explores the possibilities of geometrical assessment tools in $3 \mathrm{D}$.

\subsection{Construction phases of the Cathedral's central body}

The Tortosa's Cathedral chronology is partially registered in the Cathedral Construction Accounts (Llibres d'Obra) which are preserved at the Chapter Archive of Tortosa (ACTo.). The historical information and the masonry assesment were studied in the works (Lluis i Ginovart 2002) and (Almuni i Balada 1991; Almuni Balada 2007), where the main construction phases were defined, despite of the lack of information of some historical periods. The construction of the new Gothic Cathedral caused the progressive substitution of the original Romanesque cathedral in a process where the two buildings coexisted (Figure 1).

The construction of the new Gothic Cathedral began from the apse, and when it was completed, the works continued with the first section of the nave (1441-1495). There is an emptiness in documentary information of this period, however the works continued with the progressive substitution of the Romanesque building. Sections were completed sequentially from the chapels to the central nave, like happened in Mallorca's Cathedral (Domenge i Mesquida 1999).

The following two sections were built during the period (14951575), and in 1597 the cathedral was consecrated for the second time. In seventeenth century began the construction of the new Baroque facade and the de-construction of the Romanesque, which began on 1703 (O'Callaghan 1888). Consequently, both constructions coexisted until the beginning of the eighteenth century, and once the Romanesque remains were dismounted, the Gothic Cathedral was completed with the vaulting of the two last structural sections. The Cathedral was consecrated for the last time on 1757.
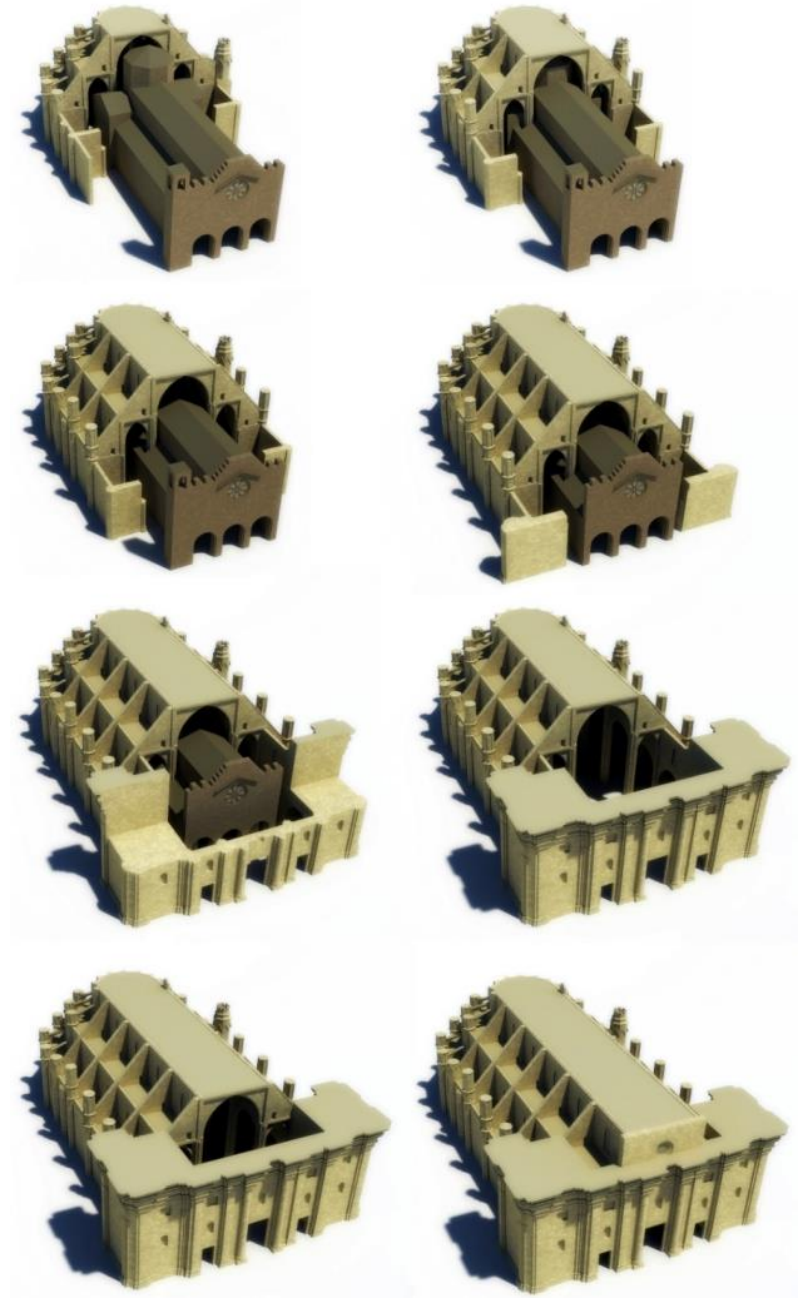

Figure 1. Construction phases of Tortosa's Cathedral's central body (1441-1757).

\section{METHODOLOGY}

The data used for the study was obtained by a Terrestrial Laser Scanner during two measurement campaigns. The first survey (Campaign 2013, Josep Lluis i Ginovart, Agustí Costa, Josep M. Puche. Leica Scan Station C10, position accuracy $6 \mathrm{~mm}$ at $50 \mathrm{~m}$ ) focused on the indoor spaces, while the second survey (Campaign 2014-15, Josep Lluis i Ginovart, Agustí Costa, Sergio Coll. Leica Scan Station P20, position accuracy $3 \mathrm{~mm}$ at $50 \mathrm{~m}$ ) completed the remaining parts of the building.

The architectural layout complexity required a large number of stations to avoid occlusions in the model. The first survey required 32 stations for the apse and 6 stations for the nave, using a medium density scanning mesh (the lecture mesh was set at 1 point per lineal $\mathrm{cm}$ at $10 \mathrm{~m}$ of distance). 25 targets strategically distributed around the entire space to reference each position within the same coordinate system. The second survey involved the remaining parts of the nave and the exterior, and required 77 stations and 47 targets. The density of the obtained point cloud is more than 624 million points (Figure 2). 


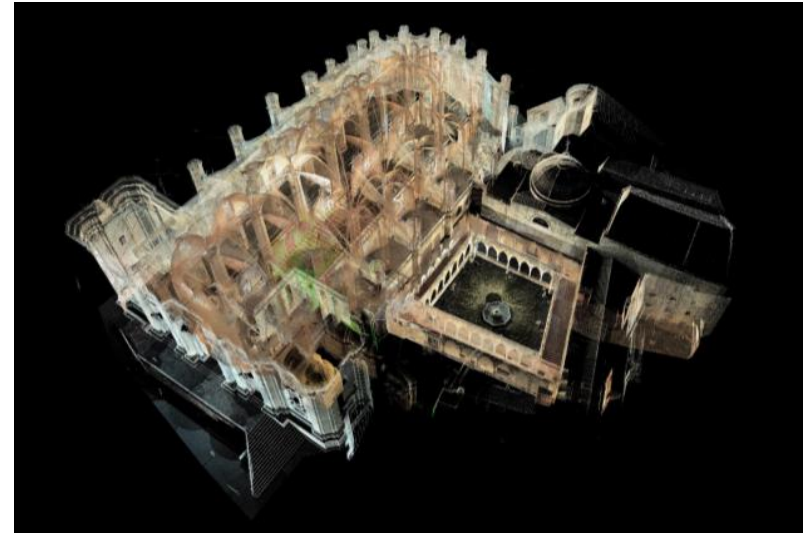

Figure 2. Point cloud visualization of Tortosa's Cathedral.

The software Cyclone was used to process the point cloud. It automatically registered the reference targets of each station and placed the point clouds in the same local coordinate system. A tolerance of $3 \mathrm{~mm}$ was defined for the joining of the different point clouds. In a second stage, the program 3DReshaper was used to generate the 3D mesh of the model from the selected points. The mesh density was adjusted at an average triangle size of $2.5 \mathrm{~cm}$, which was later refined.

The assessment of vault's geometry was focused on the nave of the cathedral. Two procedures were used. Firstly, a topographical representation of the vaulted ceiling with elevation lines placed every $15 \mathrm{~cm}$, was performed. It was obtained from the 3D mesh, using the program Rhinoceros (Figure 3), and revealed formal differences between vaults which should have exactly the same shape (Figure 4).

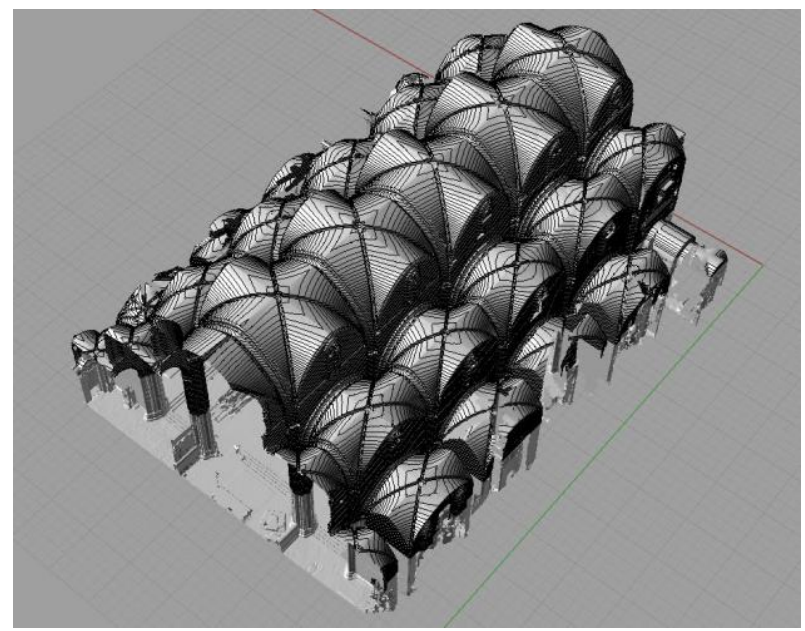

Figure 3. Topography of the vaults of Tortosa's Cathedral (1441-1575).

Secondly, these formal deviations between vaults were assessed using the 3Reshaper.The aim of the point cloud assessment is to analyse the geometry of the vaults considering the overall surface. Due to the complexity of the shape of Gothic vaults, it was discarded to use standard primitive shapes to perform the comparison. Thus, a horizontal comparison plane (PC) was defined to measure the range of distances between each point and the mentioned comparison plane. These were located at the impost lines of the vaults. In order to obtain comparable values in the assessment of the point clouds, their location was defined from the average value of the height of the impost of every vault. These heights were registered from cross sections of the vaults, where the moulding of the impost could be easily identified, and the values were introduced on a spreadsheet to calculate the average values. Three heights were defined to locate the (PCs), one for the Central Nave (NC), another for the Gospel Side Nave (NLE) and another for the Epistle Side Nave (NLD).

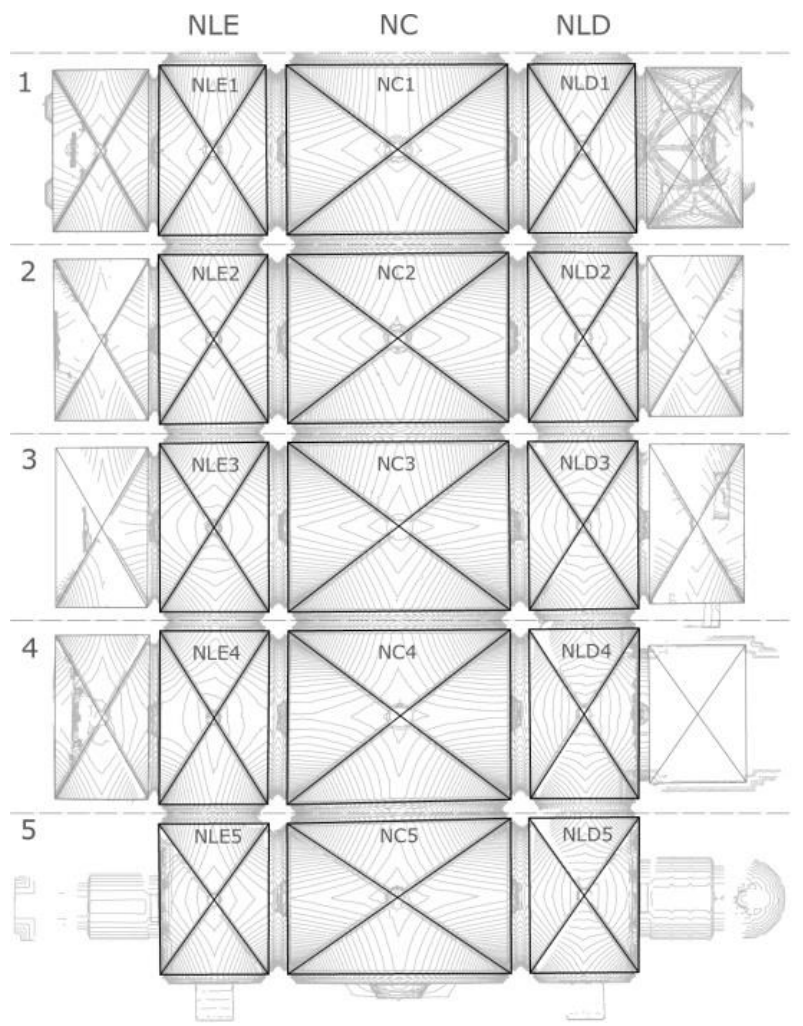

Figure 4. Topography and nomenclature of vaults.

\section{RESULTS}

The proposed methodology allowed to obtain both qualitative and quantitative data about the geometrical differences between the vaults of the central body of Tortosa's Cathedral. The results obtained in the chapels are not analysed, since the geometrical solution are not always the same and as well, there are some occlusions that distort the comparative assessment.

The program 3D Reshaper allows to compare a point cloud with a reference surface to obtain the range of distances between them. The reference shapes in these case were horizontal planes, which were located at three different heights, according to the average value of the height of the impost for every nave. Thus, the three heights that were defined to locate the PC were: one for the central nave $(\mathrm{NC}=15.420 \mathrm{~m})$, and two for the lateral naves, Gospel side $(\mathrm{NLE}=12.047 \mathrm{~m})$ and Epistle side $(\mathrm{NLD}=$ $12.104 \mathrm{~m})$

Once (PC) planes were defined, the range of distances between them and the point cloud of each vault were obtained individually (Figure 5). The vaults compared have the same geometrical properties theoretically, since the construction typology is the same for the five structural vanes. Therefore, it is possible to identify common patterns from the formal deviations. 

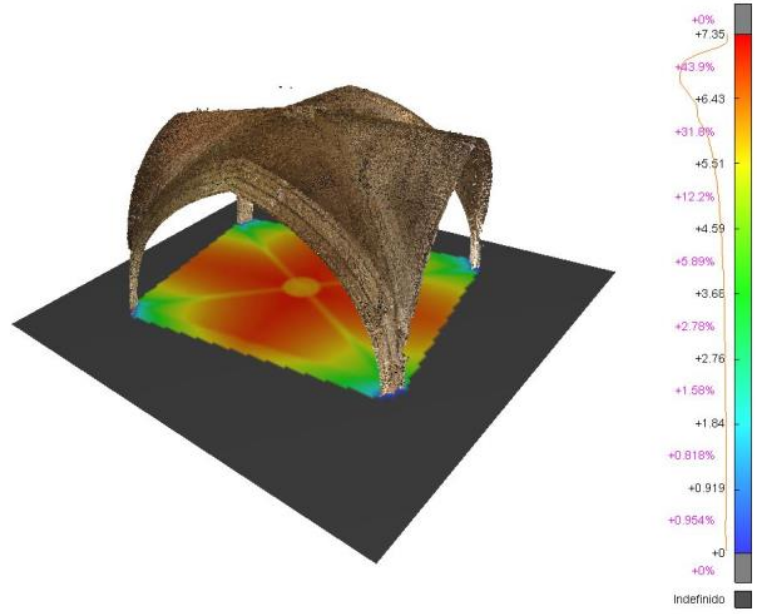

Figure 5. Example of comparison between the point cloud of a vault and the corresponding reference plane.

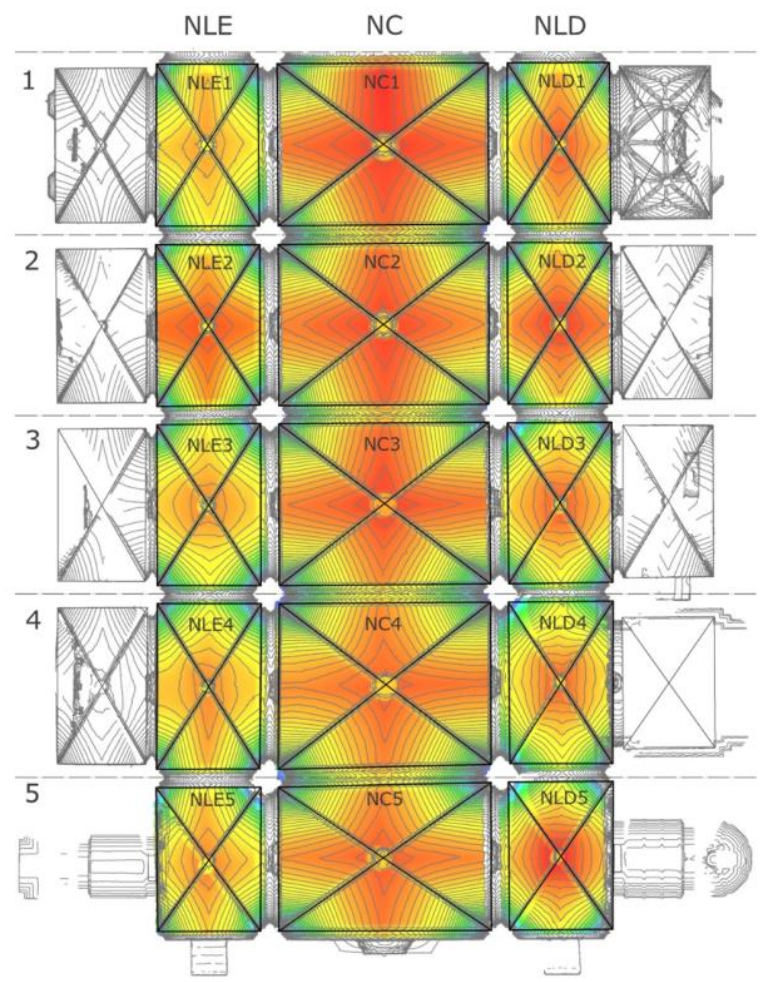

Figure 6. Topography and ranges of the vaults' heights.

The topographical representation of the vaults, which includes the representation of the ranges of distances, revealed significant differences between them. These data allow a very intuitive interpretation of the vaults' formal alterations (Figure $6)$.

In general terms, the topography of the central nave shows that the vault $\mathrm{NC} 1$ is the highest, and the rest of the vaults are progressively lower. In addition, punctual anomalies are identified, among which highlights that the masonry web of vault $\mathrm{NC} 1$ adapts to the presbytery's arch, which is higher than the other arches.

Furthermore, several formal anomalies are identified at lateral naves. The most relevant are:
- $\quad$ The vaults of the Gospel side (NLE) and the Epistle (NLD) have relevant formal differences.

- [NLE2, NLE3, NLD2] are very similar between them, and slightly different to the other vaults. The topography shows that the other vaults have a steep slope, which causes a reduction of the passive thrusts towards the supporting elements.

- [NLD3, NLD4 NLD5] have the same formal typology, which is more stilted than the rest. NLD5 has de lowest slope.

Following, it was possible to define quantitatively the formal differences between the vaults of the same typology, and to identify groups of vaults according to the correspondence of distance ranges.

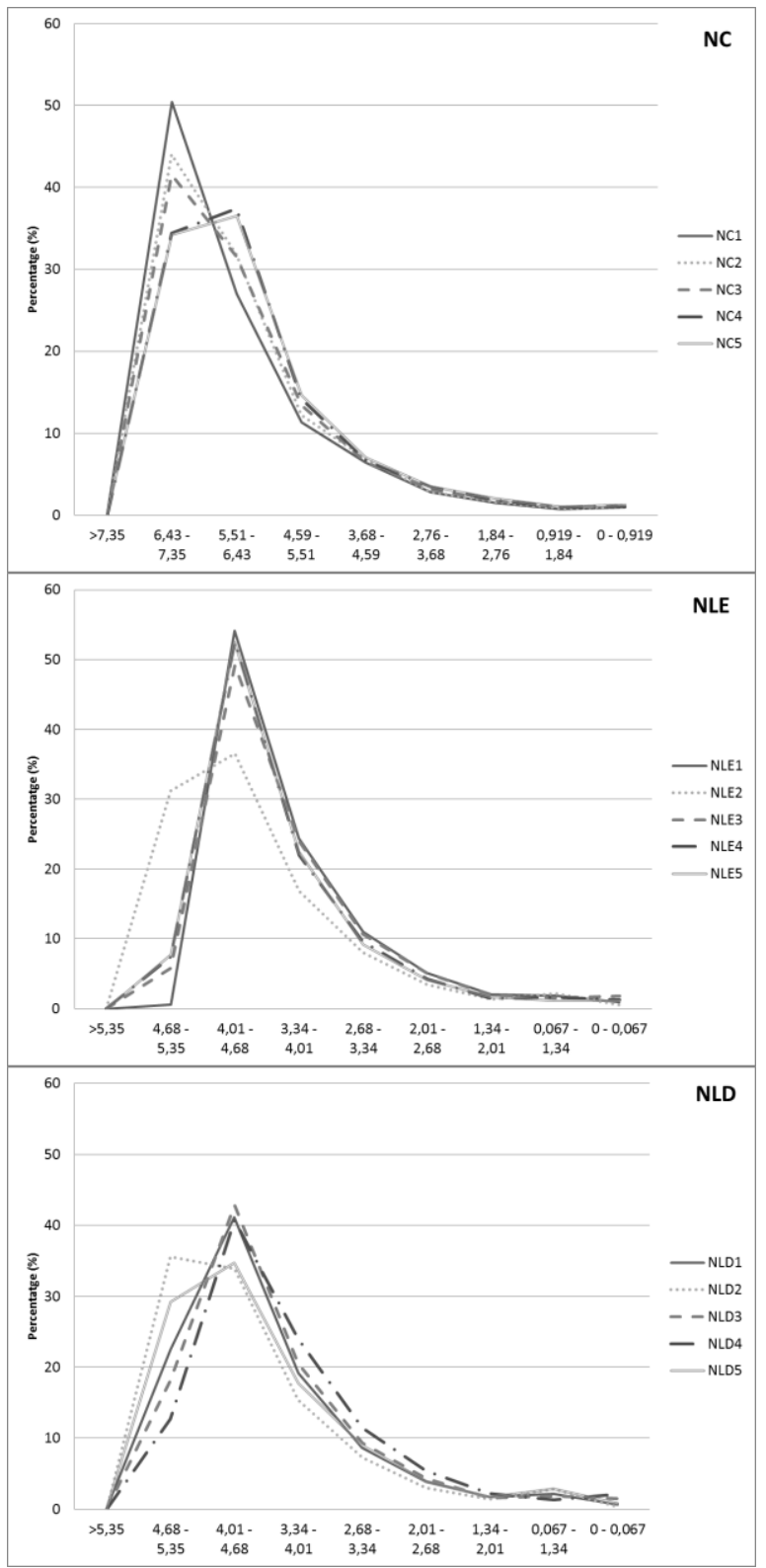

Figure 7. Ranges of distances between vaults and comparison plane (PC): a) Central Nave (NC), b) Lateral Nave, Gospel Side (NLE), c) Lateral Nave, Epistle Side (NLD). 
There are two patterns at the central nave (NC): one for the vaults [NC1, NC2, NC3] and another for the vaults [NC4, NC5] (Figure 7a). As well, the vaults of the first group have the greater distances from the plane (PC), especially (NC1). The range of distances with a higher percentage of points $[36.5 \%$ $50.4 \%]$ is $[551-735 \mathrm{~cm}]$.

In the case of lateral naves, the results show that in (NLE) all the vaults have the same pattern except (NLE2) (Figure 7b). Otherwise, in (NLD), NLD2 and NLD5 have a similar range of distances, which are lower than the vaults of the opposite side (Figure 7c). The higher range of distances for both sides are [401-535 $\mathrm{cm}]$ with a percentage of points between $[35.6 \% \mathrm{y}$ $54.1 \%]$.

\section{DISCUSSION}

Two groups of vaults were identified through the 3D assessment at the Central Nave [NC1, NC2, NC3] and [NC4, NC5], which in general terms, are lower and have a similar distribution of distances. Otherwise, at Lateral Naves (NLE and NLD) the vane 2 is the lowest, whereas the rest are similar, even though, minor sub-groups can be defined between similar vaults.

Thus, results show a progressive change in height of the structural sections from the 1st to the 5th. Keystones are very similar in height at the Central Nave (NC), but according to the ranges of distances, the vault $\mathrm{NC} 1$ is the highest, while [NC4, NC5]. Otherwise, the highest vaults of the lateral naves are located at the final sections.

Furthermore, lateral naves have differences in height between one side and another. In general terms, the central part of the vaults of the Gospel side (NLE) tend to be higher than the one in the Epistle side (NLD), except in the $2^{\text {nd }}$ vane, where values are similar. This changes the load distribution of the masonry web. The passive thrust of the web towards the supporting arches is therefore higher at this side. These differences do not have a relevant impact at the overall stability, considering that the magnitude of the thrusts is nothing compared to the structure's scale. Even though, this information is important to understand the mechanic behaviour of the vaults.

Those formal anomalies can be related with the building's construction history. The main dimensional variations can be caused by the stake out, the execution, or can be also can be caused by movements of the masonry structure. Between the three possibilities, the last one is not considered in Tortosa, since the vertical elements are perfectly plumbed. It is barely impossible to distinguish the cause of movements in the structure between the other two remaining options, but these are caused in any case by the construction process.

\section{CONCLUSIONS}

The use of devices such as a Terrestrial Laser Scanner in architectural heritage, makes it possible to survey these complex constructions in a fast way, safe and with an accuracy almost impossible to obtain before. The availability of these techniques, along with the development of specific software, allow to investigate new strategies of assessing heritage. These improvements on the available geometrical data have a direct impact in the maintenance and restoration procedures.

The methodology presented for the geometrical analysis of the masonry vaults of Gothic Tortosa's Cathedral, allowed to obtain relevant data, both quantitative and qualitative, from the point cloud with simple procedures. Tendencies in the geometrical variations of the vaults were identified, which can be related to the construction phases of the Tortosa's Cathedral's central body. In addition, the detailed topography makes it possible to deepen in the understanding of the mechanical behavior of the masonry.

The proposed methodology can be easily used for the assessment of any kind of vault, but it is especially useful in the case complex shapes. This information is of great value for the building's preservation and maintenance, yet also for the construction's history awareness, since it is possible to go far beyond usual history-graphical methodologies.

\section{References}

Almuni Balada, V., 2007. La catedral de Tortosa als segles del gòtic. 2 vols, Barcelona.

Almuni i Balada, V., 1991. L'Obra de la Seu de Tortosa : 1345 1441, Tortosa: Cooperativa Gràfica Dertosense.

Benito, M.A., 2011. La Catedral de Ávila: Evolución constructiva y análisis estructural. $\mathrm{PhD}$ thesis. Escuela Técnica Superior de Arquitectura de Madrid. Universidad Politécnica de Madrid.

Bonali, E. et al., 2014. Deformation of Ancient Buildings inferred by Terrestrial Laser Scanning methodology: the Cantalovo church case study (Northern Italy)*. Archaeometry, 56(4), pp.703-716. Available at:

Domenge i Mesquida, J., 1999. L'obra de la seu. El procés de construcción de la catedral de Mallorca en el tres-cents, Palma: Institut d'Estudis Baleàrics.

Fassi, F., Achille, C. \& Fregonese, L., 2011. Surveying and modelling the main spire of Milan Cathedral using multiple data sources. The Photogrammetric Record, 26(136), pp.462-487.

Grussenmeyer, P. et al., 2008. Comparison methods of terrestrial laser scanning, photogrammetry and tacheometry data for recording of cultural heritage buildings. International Archives of Photogrammetry, Remote Sensing and Spatial Information Sciences, 37 (B5), pp.213-218.

Kadobayashi, R. et al., 2004. Comparison and evaluation of laser scanning and photogrammetry and their combined use for digital recording of cultural heritage. International Archives of Photogrammetry.

Lerma García, J.L. \& Biosca Tarongers, J.M., 2008. 3D RiskMapping: teoría y práctica del escaneado láser terrestre, [València: Universitat Politècnica de València].

Lluis i Ginovart, J., Costa, A., et al., 2014. Assessment of the construction process of the Cathedral of Tortosa. Journal of Architectural Conservation, 20(3), pp.156-169.

Lluis i Ginovart, J., Toldrà, J.M., et al., 2014. Close Range Photogrammetry and Constructive Characterization of Masonry Gothic Vaults. Revista de la Construcción, 13(1), pp.47-55.

Lluis i Ginovart, J., 2002. Geometría y diseño medieval en la catedral de Tortosa. La catedral no construida. Universitat Internacional de Catalunya.

Lluis i Ginovart, J. et al., 2013. Gothic construction and the Traça of a heptagonal apse: The problem of the Heptagon. 
Nexus Network Journal: Architecture and MAthematics, 15(2), pp.325-348.

Lluis i Ginovart, J. \& Costa Jover, A., 2014. Design and medieval construction: The case of Tortosa catedral (13451441). Construction History, 29(1), pp.1-24.

Lluis i Ginovart, J., Costa Jover, A. \& Fortuny Anguera, G., 2015. Elementos auxiliares de construcción en la arquitectura gótica. El pilar major" de la catedral de Tortosa. Informes de la Construcción, 67(537).

Lluis i Ginovart, J., Costa-Jover, A. \& Coll-Pla, S., 2016. La determinación del concepto de homogeneidad versus resistencia en los pilares de una catedral gótica mediante técnicas no invasivas. Informes de la Construcción, 68(543).

Lluis i Ginovart, J., Costa-Jover, A. \& Coll-Pla, S., 2014. La reconstrucción de un palimpseto románico mediante técnicas no destructivas. Informes de la Construcción, 66, p.536.

Lluis i Ginovart, J., Costa-Jover, A. \& Coll-Pla, S., 2015. Placing the keystone of the vault over the presbytery in Tortosa Cathedral, Spain (1428-40). Construction History, 30(1), pp.121.

Lluis i Ginovart, J., Costa-Jover, A. \& Coll-Pla, S., 2016. Techniques of massive data capture: A comparative approach for the assessment of complex spaces in architectural heritage. Revista de la Construcción, 15(1), pp.42-50.

Lluis i Ginovart, J. \& Llorca, A., 2000. Pla Director Sancta Maria Dertosae. Bisbat de Tortosa, ed., Departament Cultura Generalitat de Catalunya.

Martínez, S. et al., 2013. Recording Complex Structures Using Close Range Photogrammetry: The Cathedral of Santiago De Compostela. The Photogrammetric Record, 28(144), pp.375395.

O'Callaghan, R., 1888. Anales de Tortosa III, Imprenta Católica de Gabriel Llasat.

Pavlidis, G. et al., 2007. Methods for 3D digitization of Cultural Heritage. Journal of Cultural Heritage, 8(1), pp.93-98.

Pesci, A. et al., 2012. Laser scanning and digital imaging for the investigation of an ancient building: Palazzo d'Accursio study case (Bologna, Italy). Journal of Cultural Heritage, 13(2), pp.215-220.

Quagliarini, E., Clini, P. \& Ripanti, M., 2016. Fast, low cost and safe methodology for the assessment of the state of conservation of historical buildings from 3D laser scanning: The case study of Santa Maria in Portonovo (Italy). Journal of Cultural Heritage.

Sternberg, H., 2006. Deformation measurements at historical buildings with terrestrial laserscanners. , XXXVI(September), pp.303-308.

Vendrell, M. et al., 2008. Santa Maria del Mar. Estudi històricconstructiu, materials de construcció i estabilitat estructural., Barcelona: UB-Patrimoni, Veclus, UPC.

Yilmaz, H.M. et al., 2007. Importance of digital close-range photogrammetry in documentation of cultural heritage. Journal of Cultural Heritage, 8(4), pp.428-433. 